Preprint, to appear in: Comparative Social Policy and the Public-Private Dichotomy / Daniel Béland ... (eds.) Houndsmills, Basingstoke: Palgrave Macmillan, 2008

\title{
Germany: The Public-Private Dichotomy in the Bismarckian Welfare Regime
}

\author{
Sven Jochem \\ University of Luzerne \\ E-Mail: Sven.Jochem@unilu.ch
}

November $18^{\text {th }}, 2007$

Words: 7.120

Konstanzer Online-Publikations-System (KOPS)

URN: http://nbn-resolving.de/urn:nbn:de:bsz:352-opus-76984 URL: http://kops.ub.uni-konstanz.de/volltexte/2009/7698/ 


\section{INTRODUCTION}

The German welfare state has undergone fundamental reforms over the past three decades. Since the early 1980s, various governments changed the programmatic contours of German social policies. Beyond the question of how various national governments could push through these reforms under the conditions of federalism, divided government ( jointdecision trap'; Scharpf 1988, 2006), corporatism and increasing party competition, this chapter focuses on the changing contours of the public-private mix in health and pension policies. The argument of this chapter is that privatization, understood as a "risk shift" (Hacker 2004, 2006), has taken place in the German welfare state. However, because this welfare state was, and largely remains, a highly interwoven social insurance state in which the state and social partners (for example, labor and business organizations) coincidentally finance and regulate important welfare programs, these reforms do not imply that the federal government lost its prominent role in social policy. Rather, the national government still strongly regulates benefits, contributions, and other programmatic features of public and private social policies.

As a result of these reforms, the relationship between the state and market forces in Germany has become even more complex, and the boundaries between 'public' and 'private' social policies increasingly blurred. This German case study provides broad evidence in favor of the argument that the analytical distinction between 'public' and 'private' is a 'murky terrain' (Rein and Rainwater 1986: 203). Instead of the traditional, clear-cut analytical distinction between 'public' and 'private', one can speak of a continuum that opens new perspectives to investigate the fuzzy interplay between the 'market' and the 'state' in social policies. 
Three main sections comprise this chapter. First, after a brief discussion concerning the development of the German welfare state, developments in health politics and policies are reported, the analytical perspective being to trace empirically shifts in the public-private mix. Second, the development of pension politics and policies is discussed. In this policy area, major shifts in the public-private mix were triggered by 'red-green' (i.e. Social Democratic and Green coalition) governments. The final section discusses future challenges and possible reforms.

\section{NOTES ON THE GERMAN WELFARE STATE}

The German welfare state is a prototype of a 'social insurance state'. Public social security schemes are financed mainly through payroll contributions. Employees and employers are obliged to contribute to the financing of the welfare state (albeit to different degrees and with important exceptions). In most areas of the welfare state, the burdens are equally shared between employees and employers. Moreover, the federal executive cofinances several social security schemes with general tax revenues. In the past, the legitimacy of this financial contribution of the state to the social security system was intensely debated (Bleses and Seeleib-Kaiser 2004, Jochem 2007).

Following the 1990 German Reunification, the institutional design of West Germany's welfare state was successfully expanded to the former East Germany. Challenged by the severe economic crisis in the East and the task of financing social security despite high unemployment in that part of the country, massive financial transfers within social security schemes took place. Since 1990, considerable amounts of money have been transferred from West German to East German social security schemes, thus amounting to another layer of transfers in addition to official transfer system that 
redistributes tax revenues between the national government and the now sixteen states or 'Länder' ('Länderfinanzausgleich'). In 2003, for example, 5.7 billion $€$ were transferred from West German to East German public pension funds alone, and between 1992 and 2003 , transfers in public pension funds were estimated at approximately 55 billion $€$ in total (Jochem 2007).

German Reunification meant both an expansion of the state and a reduction of the role of the public sector in social policies. This seemingly contradictory remark rests on the observation that, after German Reunification, the federal government had to inject more tax revenues into social policy schemes, thereby gradually eroding the traditional emphasis on social insurance. On the other hand, and especially visible in health policies, the 'pure' public system of East Germany was terminated and the West German mix of public social insurance and private actors was transferred into the 'neue Länder'. Since 1992-93, as this territorial transformation of the German welfare system was by and large completed, welfare reforms have attempted to alter the public-private mix. These reforms and their impact on the public-private mix are discussed in detail in the two following sections.

\section{HEALTH CARE}

Health insurance systems are often fragmented, yet to varying degrees governments intervene into different components (Immergut 1992). Many analyses focus on the mode of financing or spending (for example, Castles 2004). The state may also serve as a provider of health services or as a more or less active regulator of private health services or private health markets. In this respect, the German social insurance system represents a peculiar mixture of public and private insurance schemes, of public and private services and, finally, of public governance and private self-regulation. Thus, as far as the public-private 
dichotomy is concerned, the German health care system was and remains a public-private hybrid.

Germany pioneered public and mandatory social security schemes. Already in 1883, the government of the German 'Reich' under Chancellor Bismarck introduced a national statutory health insurance system. From the beginning, corporatist and federal elements in health policies dominated (Wehler 1995). The incorporation of organized labor and business interests as social partners into the administrative boards of the regionally differentiated statutory health insurance funds ('Krankenkassen') was meant to soothe the labor movement while enabling these social partners to regulate health issues in collaboration with the national government.

In the following decades, a trend not unique to Germany is the stepwise inclusion of many other collective actors into the health policy network, such as professional organizations representing pharmacists or statutory health insurance physicians. The governance of the German health care system has also been shaped by a national decisionmaking system where the central government not only has to negotiate reforms with organized interests but in many cases with the 'Länder', which are represented through the 'Bundesrat' (i.e. the upper house of the German parliament). Both corporatism and federalism have survived dramatic regime changes in German history and they still determine the institutional configuration of this policy area (Schmidt 2005).

At the heart of the German health care system is statutory health insurance ('Gesetzliche Krankenversicherung' or GKV). This public insurance is de facto compulsory for all employees, but there are major exceptions. For example, under specific circumstances, self-employed individuals and civil servants ('Beamte') may opt out. The GKV coverage increased steadily after World War II, as particular public health insurance schemes for students, artists and farmers were founded and integrated into the public 
system. However, this trend was reversed in the mid-1970s. Since then, the proportion of the population that opts out of the GKV has increased steadily. In 1975, 4.2 million people were insured under a private health insurance scheme; this figure increased to 5.2 millions in 1985 and reached 6.6 million in 1990. Since German Reunification, the number of privately insured people has increased even further. Today, approximately 8 million people participate in private health insurance schemes (approximately 10 per cent of the German population). Political decisions taken during the 1980s opened several pathways for the insured to leave the GKV. This is especially true for civil servants ('Beamte') and high wage employees, who have been granted more and more freedom to choose between public and private health insurances. In addition, since the early 1980s, private supplementary health insurance schemes, which deal with costs not covered by the GKV, have also spread. Today approximately 9 per cent of the German population participates in these supplementary schemes (Rothgang, Cacace, Grimmeisen, Helmert and Wendt 2006: 324$325)$.

In the 1980s, to contain health spending, the center-right governments implemented various reforms. As early as 1983 and 1984, the first reforms were aimed at increasing private health co-payments. This trend was further strengthened by the major health care reform in that decade, the 1988 'Gesetz zur Strukturreform im Gesundheitswesen'. Because the interests of the providers of heath care services were effectively protected by the smallest party in the coalition government (the liberal Free Democratic Party, FDP), most cost containment measures favored the expansion of private co-payments in the German heath care market. This was especially the case for cost-intensive dental treatment. Despite the government's ambition to make efficient reforms to the institutional structure of the German health care system, this 'Strukturreform' could not shake up the institutional status quo. Organized interests from the supply side of the health care market, such as 
pharmacists or physicians, as well as the FDP in government blocked any attempts to promote greater competition between health service providers. Due to the pivotal position of the FDP, ambitions to restructure the public-private mix in health care were politically unfeasible and the status quo remained mainly unchanged.

From 1990 to 1992, as the West German health care system was extended to former East Germany, further attempts to change health care institutions were launched. In general, the Social Democratic Party (SPD) in the East defended some public institutions of the former East Germany's health care system like outpatient centers. However, due to the time pressure of Reunification and the lack of political support for these interests within the West German SPD and other parties, these attempts failed (Ritter 2006). Thus, the health care system in reunified Germany is to a very great extent the system as it had developed in West Germany, with its peculiarly fuzzy public-private mix.

Political frustration over the 1988 reform and further increased health spending (as well as rising health contribution rates of the GKV) led the center-right government to activate new reform negotiations in 1992-93. In contrast to what occurred before the 1988 reform, organized interests were excluded from official negotiations. In contrast to the situation prevailing in the 1980s, the largest opposition party, the SPD, was included in the reform talks, which were held behind closed doors in Lahnstein, a small city near Koblenz. The government hoped the new reform would introduce more competition between health care service providers. At the same time, every employee was granted the freedom to decide which health insurance fund he or she would join. With this political 'compromise from Lahnstein', a financial coupling of the different health funds was implemented and the unrestricted freedom for private physicians to enter the health care market was limited. Further, the financing of public hospitals was altered. The goal was to contain costs through switching the financing mechanism from overall transfers to specified individual 
transfers.

Politically, however, the 'compromise from Lahnstein' became a 'traumatic experience' for the FDP (Lehmbruch 1998: 172, translated by the author). Consequently, from its enactment to the end of the 'Kohl Era' in 1998, the FDP blocked all further attempts to negotiate social policy reforms again with the SPD (with the exception of the 1994 long-term care scheme, which falls beyond the scope of this chapter). A second consequence of the above-mentioned compromise was that the FDP strengthened its liberal profile, thus trying to further protect private suppliers in the health market. Under the circumstances of divided government after German Reunification, this strategy undermined the political foundation of further successful reforms and, hence, this political compromise on health care reform came at a high political price for the center-right government.

The political stalemate became obvious during the 1996 and 1997 reform negotiations. This time, although organized interests again returned to the reform process, opposition parties were excluded from it. In addition to institutional rearrangements in the hospital sector and the greater freedom for the insured to switch to other health insurance funds if the insurance fund increased their contribution rates, most measures resulted in a further expansion of private co-payments. After 1998, the newly elected red-green government immediately lowered co-payment rates. As a consequence, the total amount of the co-payments dropped significantly. While the amount of the private co-payments increased from 0.6 billion $€$ in 1991 to 2.7 billion $€$ in 1998 , it decreased to 2 billion $€$ in 1999 and remained stable at 1.8 billion $€$ until 2002 (Busse and Riesberg 2004: 74).

After intense political debates and a compromise between the red-green government and the largest opposition party (CDU/CSU), the Health Care Modernization Act ('Gesundheitsmodernisierungsgesetz' or GMG) reversed the declining trend of private copayments after 2004. This reform mainly switched the burden to contain public health care 
spending towards increased private co-payments. General exemptions due to poverty or other reasons were abolished and regulations for partial exemptions were tightened. It should be noted that this increased 'risk privatization' (Hacker 2004, 2006) goes hand in hand with a decline in public funding. For example, the share of tax revenues used to finance the health care system declined from 13 per cent in 1992 to 7.8 per cent in 2002 (Busse and Riesberg 2004: 58). It should be further added that the overwhelming part of the costs is financed through the public health insurance funds. Official data classify these financial sources as public, which is problematic at best. As this money is injected through the employee and employer contributions, the label of 'public' funding partially veils the private component of the German health care system and, consequently, overestimates the direct role of the state.

As elsewhere in the OECD, the health care business in Germany is a growth industry. Health spending relative to the national income in Germany has risen from 6.2 per cent in 1970 to 10.3 per cent in 1995 and, finally, to 10.9 per cent in 2004 . This increase is in line with the OECD trend (Rothgang et al. 2006). Within the OECD, only the United States (15.3 per cent) and Switzerland (11.6 per cent) devote a greater portion of their national income to health care. As for the public share of health care spending in Germany, it was 78.2 per cent in 2004 (OECD 2006). Thus, among OECD countries, Germany ranks near the middle in terms of public health care spending, significantly below Luxembourg (90.4 per cent public) and far above the United States (44.7 per cent). It should be noted that since 1995, the relative financial weight of the public sector decreased by approximately 2 percentage points in Germany (OECD 2006).

But the public-private mix in Germany is more complex than these data imply prima facie. In fact, private households are responsible for the lion's share of financing. Analyzing cash-flows in the German health care system, it can be shown that, in 2004, 
private households spent 147.5 billion $€$ to finance the system. The employers' contribution amounted to 112.8 billion $€$ whereas the state only contributed 52.8 billion $€$ (SBA 2006:

22). These cash-flow data show that private households are the main revenue source for the German health care system. The SBA report further shows that the state's relative financial contribution to the German health care system has declined steadily. While representing about 19 per cent of health care spending in the mid-1990s, the state's share declined to 16.9 per cent in 2004 . Although there are no up-to-date spending data available, we can assume that, as a consequence of the 2004 reform, the share of private financing has continued to increase.

As suggested above, corporatism and federalism structure the organizational landscape of the German health insurance system. Policy competencies are delegated to membership-based, self-regulated organizations representing both the supply side (for example, physicians and regional sickness funds) and the demand side (for example, those who 'consume' health services and which are mainly represented by the unions). These organizations are formally integrated into statutory insurance schemes. In the statutory health insurance system (GKV), regional sickness funds, their associations, and the associations of GKV-affiliated physicians have assumed the status of quasi-public corporations. Through joint committees, organizations from both the supply and the demand sides are entitled to define health care benefits, prices and standards. These committees may even sanction their members, if they do not follow the defined rules of health services. Hence, the German health insurance system is a combination of horizontal corporatist negotiation and vertical negotiation within a federal state. Today, there are 320 different quasi-public sickness funds with slightly different contribution rates. On average, the contribution rate is today 13.8 per cent in former West Germany and 13.5 per cent in former East Germany (SVR 2006). 
Due to the specific public-private mix in the provision of services, the German health care system has had a pronounced private, or market-based, profile. This market emphasis characterizes private pharmacies and office-based ambulatory care and dentistry. However, the role of the private sector is increasing even in traditionally state-dominated areas. While there is no strong push towards 'pure' privatization, a trend towards the multiplication of private, for-profit hospitals is observable. Between 1990 and 2002, for example, the share of public hospital beds declined from 62.8 per cent to 53.9 per cent of the total number of beds. During the same period, the share of private yet non-profit beds increased slightly from 33.5 per cent to 37.7 per cent. Meanwhile, the share of private, forprofit hospital beds increased from 3.7 per cent to 8.3 per cent (Busse and Riesberg 2004: 56). This trend continues today.

Privatization and the strengthening of market rules have occurred in other aspects of the German health care system. During the 1990s, the federal government expanded choice in sickness funds. In a comparative perspective, choice is as 'liberal' as in Switzerland, for example. Although comparing differences in health care regulations across countries is difficult, Greß (2006) shows that, on average, German citizens switch from one health insurance plan to another more often than Swiss or Dutch citizens. In a sense, this dimension of the German health care system has been liberalized with great success, as the population actively takes advantage of opportunities to switch from one insurer to another.

A disadvantage to this 'liberalization', however, is that an increasing portion of the population has been excluded from the private and statutory components of the German health insurance system. Due to economic problems like unemployment and national initiatives aimed at restricting access to statutory or private health insurance in order to fight adverse selection, the number of persons without private or public health insurance increased during the 1990s. Relying on estimations based on 'Mikrozensus' data, Greß and 
others (2005) suggest that between 1995 and 2003, the number of uninsured nearly doubled from 105,000 to 188,000 . These uninsured individuals are mainly people who are excluded from the labor market. However, in recent years, even the share of employers living without private or statutory health insurance has increased. In 2007, the government reacted to this trend by introducing mandatory health insurance. Since April 2007, every citizen has the right to contract a basic private or statutory health insurance. Those who have lost their insurance coverage for one reason or another have now the right to gain health coverage from their last insurance fund.

Universal health insurance is only one aspect of what is known as the 2007 'statutory health insurance competition strengthening act' ('Gesetz zur Stärkung des Wettbewerbs in der gesetzlichen Krankenversicherung'). This key legislation was intended to be the core reform project of the Grand Coalition (SPD and CDU/CSU) formed in the aftermath of the 2005 elections. Immediately after these elections, the black-red coalition pushed negotiations for a 'fundamental' health care reform. However, the results were meager. Already during the 2005 campaign, the two main political parties promoted different reform strategies. In the past and into the present, the CDU/CSU has wanted to reform the German statutory health insurance system in line with the Swiss model. The SPD, in contrast, has recommended and continues to recommend a citizens' health insurance scheme ('Bürgerversicherung') that would bring all blue- and white-collar workers as well as civil servants (up to a specified income ceiling) into public statutory health insurance, leaving only small opportunities to opt out of the public system. Hence, two contradictory policy alternatives clash: one favoring the expansion of market-based protection, the other favoring the strengthening of the public GKV.

Overall, the 2007 reform implemented a number of new health care regulations. First, as already mentioned, the reform transformed health coverage into a citizenship right 
according to which public and private insurers alike must offer basic benefit packages to all citizens. This innovation is based on a broad policy consensus between the Christian Democrats and the Social Democratic Party. Second, the reform implemented several measures that should increase the level of competition within the health care market. Health insurers may offer their clients differentiated tariffs and sickness funds may now negotiate more flexible arrangements with health care providers about the price and the quality of services. Third, the structure of financing the GKV will soon be reformed. This will lead to the implementation of a unitary contribution rate across Germany as well as the expansion of the federal government's tax contribution to GKV financing. According to this new system, contributions and tax revenues will flow into one nationwide health care fund. Statutory health insurance funds will receive a flat amount for each insured person. Well-managed funds will then be able to refund a portion of each insured's contribution, whereas funds which will not able to cover costs will have to charge an additional premium to its insured. In the public debate, the introduction of the above-mentioned nation-wide health fund was highly contested and, for that reason, postponed until 2009. It is doubtful that this united fund will in fact be implemented at that time, as the next federal elections take place in the same year (if the Grand Coalition holds together until then).

The results of the next national elections will be decisive for the future of the German public-private health care mix. The SPD proposes strengthening of the public GKV and a partial integration of private health insurance funds into the public system. In contrast, the CDU/CSU proposes strengthening the private insurance funds, and to differentiate between basic (public) and supplementary (private) health insurance. It is too early to tell which conception will triumph. It is clear, however, that the outcomes of the next federal elections will decide which political camp will win the majority and which reform will take place. 


\section{PENSIONS}

The Disability and Old Age Insurance Act of 1889 ('Invaliditäts- und Altersversicherungsgesetz') marks the beginning of a public, compulsory pension insurance system in Germany (Frerich and Frey 1993: 95-101). This reform introduced mandatory insurance for blue-collar workers. Insured workers were entitled to benefits at the age of 70 with a minimum of 30 years of contributions, and they were entitled to invalidity benefits. Many workers could not benefit from this scheme because life expectancy at this time was in most cases lower than 70 years. Contribution rates depended on wage groups, but on average were 1.7 per cent. In the early decades of the 20th century, a white-collar scheme was separately introduced.

After World War II, the administrative separation between blue- and white-collar employees, which had been discarded by the Nazi dictatorship, was reestablished. As the calculation of pension benefits did not take into account inflation or wage increase, the level of benefits became inadequate by the early 1950s. During that decade, deliberations on a comprehensive pension reform resulted in the 1957 legislation. In 1956, both the government coalition (the Christian Democratic Party and two small liberal parties) and the SPD opposition submitted pension reform bills that envisioned gross wage indexation, a reform rejected both by the liberal FDP and the employers' association. Despite some resistance within the CDU/CSU, federal Chancellor Konrad Adenauer (CDU) pushed the innovation known as 'dynamic pension' ('dynamische Rente') through the Bundestag on 21 January 1957. Since then, pension benefits have been coupled towards growth in gross wages. The immediate effect of this reform was an average 65 per cent increase in old age pensions. 
In the field of occupational pensions, the 1974 Occupational Old-Age Protection Act ('Gesetz zur Verbesserung der betrieblichen Altersersorgung') emerged as the most crucial post-war legislation, setting the legal context for second pillar pensions. The Act regulated the vesting of pension entitlements for employees who move from one employer to another and safeguarded pension benefits against the risk of inflation and employer's insolvency (Schmähl and Böhm 1996: 8). It is worth noting that, since the 1970s and following a 'functional conversion' logic according to which the defining objectives of an institution are altered (Thelen 2004), the existing early retirement schemes have been increasingly used by labor and capital as an exit pathway for older workers. As a consequence, social partners shifted labor market problems, especially unemployment among older workers, to the pension system. This logic is not unique to Germany, and it has been used extensively in countries like Belgium and France, among others (Kohli, Rein, Guillemard and van Gunsteren 1991; Immergut, Anderson and Schulze 2007).

Since the 1980s, several minor reforms were implemented by the federal coalition (FDP and CDU/CSU). However, most of these reforms aimed at cost containment and, by and large, did not shift the public-private mix in pension policies. The most important of these reforms, the 1989 Pension Reform Act, enacted the very same day as the Berlin Wall broke down but implemented in 1992, even strengthened the existing institutional design of the pension system. The change from gross- to net-wage indexation was the most influential change enacted through the 1989 reform. And, from a political perspective, this reform was the last one until 2007 that was backed by all major parties in parliament (Hinrichs 1998; Schulze and Jochem 2007). In 2001, the red-green government brought about a genuine 'paradigm shift' (Hall, 1993) in German pension policies by introducing a more or less 'private' insurance pillar, the so-called 'Riester Rente'. With this reform and two others in 2004, the red-green government reshaped the traditional goals and 
institutions of the German pension system and strongly altered the public-private mix (Rüb and Lamping 2005; Schulze and Jochem 2007).

Figure 1 presents the complexity of the highly fragmented German pension system. Representing the 'sector' of a specific pension scheme, the first pillar stands for the public sector, the second for the occupational sector, and the third pillar for the private sector. This perspective makes use of the analytical distinction between the state and the market sectors. Furthermore, the term 'tier' points to the distinction between various types of pension benefits. This distinction is important because it matters a great deal whether benefits are targeted, minimum, flat-rate, earnings-related, or defined-contribution. Moreover, the distinction between mandatory and voluntary pension schemes is essential for obvious reasons.

Figure 1: The German Pension System Today

FIRST PILLAR

\begin{tabular}{|l|}
\hline Third Tier: \\
None \\
\hline First and Second Tier Combined: Earnings \\
\hline
\end{tabular}

SECOND PILLAR

\section{THIRD}

PILLAR

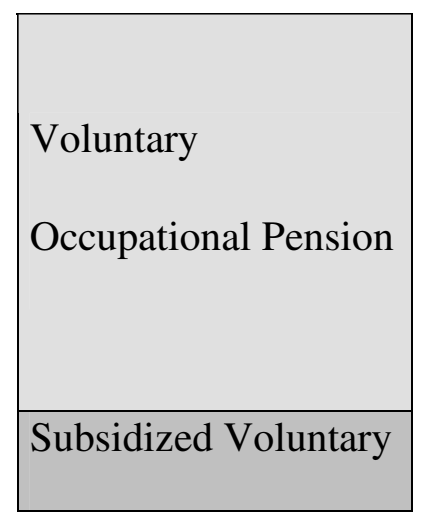

Voluntary

Private

Pension

Subsidized 

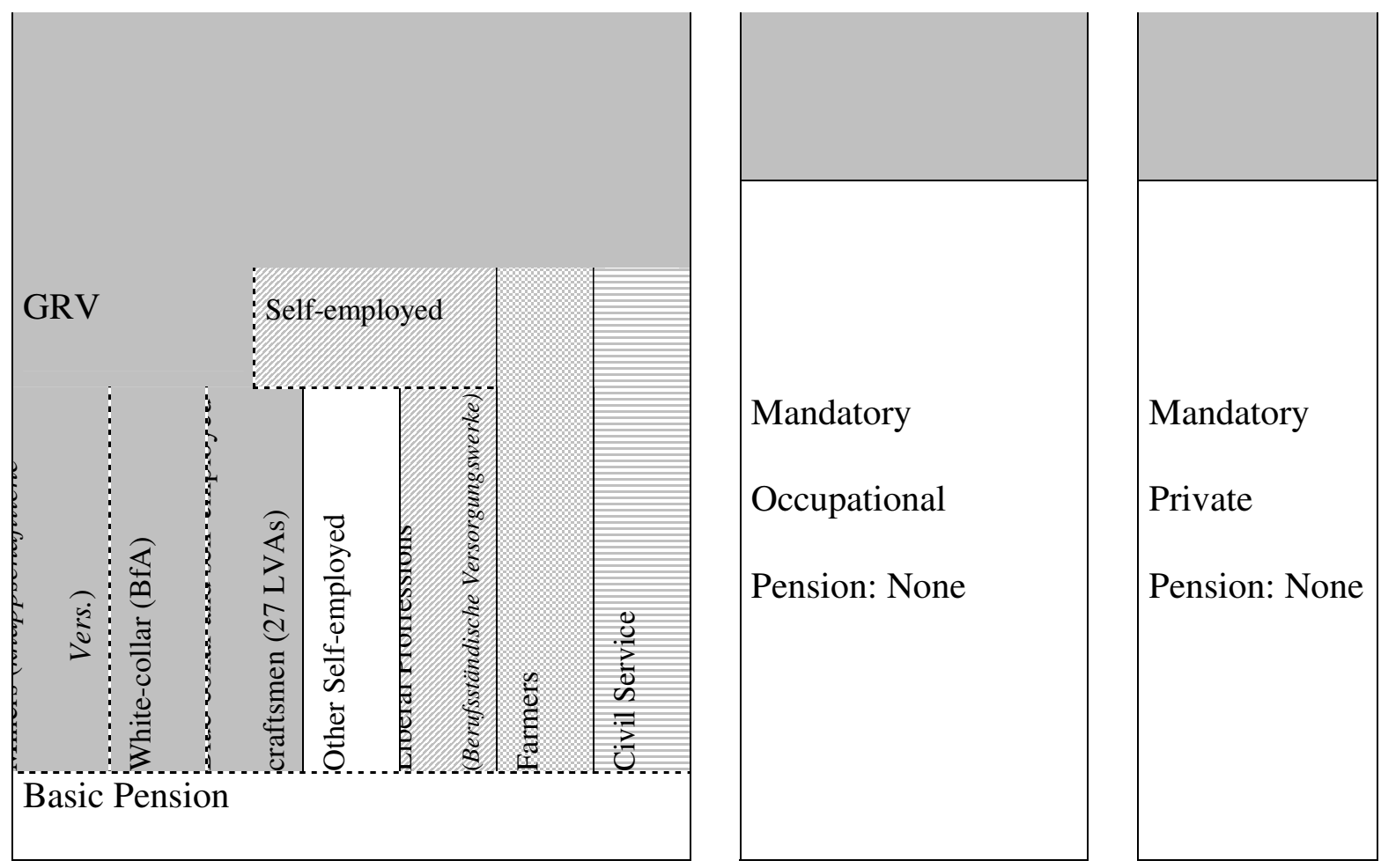

Social Assistence (bedarfsorientierte

Grundsicherung)

Source: Schulze and Jochem (2007: 674).

Disentangling this complex system further, it is also possible to differentiate between the schemes covering different occupational groups. Following a logic of occupational fragmentation that emerged since Bismarck, the contemporary German pension system is divided into the compulsory statutory pension insurance for blue- and white-collar employees, the pension scheme for the agricultural sector, coverage of civil servants ('Beamtenversorgung'), and several other occupational schemes. The statutory pension insurance ('Gesetzliche Rentenversicherung', GRV) covers approximately 82 per cent of the workforce. Although Germany has no compulsory insurance system for all types of self-employed, they can voluntarily join the state pension system. As occupational and private pensions are not mandatory, the role of the second- and third-pension pillars 
remains limited in scope. But, since the introduction of the 'Riester Rente (see below)', their importance has increased steadily due to tax subsidies from the state. For current pensioners, however, the major source of old-age income remains the first pillar pension scheme. However, the impact of the first pillar will be reduced significantly in the near future (DIA 2007).

The 23 regional pension insurance funds are united in the Federation of German Pension Insurance Institutes (Verband Deutscher Rentenversicherungsträger, VDR). The VDR is an autonomous administrative institution with a board of directors composed of an equal number of business and labor representatives. One of the main tasks of the VDR is consultation and the preparation of expert reports aimed at informing the legislative process. Hence, in Germany, data collection on pension policy is more or less in the hands of the VDR, and the government relies to a great extent on its database (Nullmeier and Rüb 1993). Organizational reforms enacted in late 2004 fused the VDR and BfA (the whitecollar umbrella pension fund) into a new 'Deutsche Rentenversicherung Bund' (German National Pension Insurance). These reforms also reduced the number of regional pension funds through regional fusions.

The public pension system is financed on the pay-as-you-go principle. Contribution rates are shared equally between the employee and the employer. The employer pays the entire contribution for employees in apprenticeship and those earning less than $400 €$. Lowincome earners with monthly wage between $400 €$ and $800 €$ wages must pay reduced but progressively increasing contributions. The German pension system is partly tax-financed, as the government subsidizes pension insurance with a grant. Since April 1st, 1998, there is a supplementary federal subsidy to cover non-contribution benefits. This lump-sum payment is financed by having increased VAT by one percentage point and, since 2000, by the revenues from an 'ecology' tax on energy. This reform increased the financial 
contribution of the state to the public pension funds. To guarantee that pension carriers always have balanced budgets, the contribution rate must increase as expenses grow.

Pensions are paid if the insured person reaches the standard retirement age of 65 , meets the requirements for long service pensions, is incapacitated for work (disability), or dies leaving his or her spouse eligible for a survivor's pension. The value of pension benefits depends mainly on the contributions paid throughout the working career and, therefore, on the level of income from employment. Contributions paid are converted into personal earning points ('Entgeltpunkte'). 'Entgeltpunkte' can also be earned through child-raising periods, military service or, until 2004, higher education.

Pensions are adjusted yearly by government decree. So far, the new pension value ('Rentenwert') has been calculated by multiplying the current pension value with the changes in the average gross wage (of the real contribution base since 2005) between the previous year and the year before that, and with the changes in pension contribution rates, including a private pension contribution rate of 4 per cent in 2009. Since January, 2005, the indexation formula further includes a demographic factor known as the 'Nachhaltigkeitsfaktor' (sustainability factor) that reflects the ratio of pensioners relative to contributors.

The most important shift in the public-private pension mix was made by the socalled Riester Reform. After some fumbling of the red-green government in social policies, in 2001 this pension reform changed the contours of the German pension scheme (Trampusch 2005). As Winfried Schmähl puts it, the 2001 reform marked a 'paradigm shift' in German pension policies (Schmähl 2003; see also Hering 2002; Hinrichs 2004 Rüb and Lamping 2005). The replacement rate of the first pillar was significantly reduced. The joint (employer and employee) contribution rate was capped at 20 per cent of gross wages. In order to compensate for the traditional principle that the first pillar should 
maintain the pensioner's standard of living ('Lebensstandardsicherung'), the government subsidized private pensions ('Riester-Rente'), especially targeting lower-income workers. After political negotiations and the intervention of trade unions, occupational pensions ('Entgeltumwandlung') were included in the system of tax incentives, thereby giving the labor market parties new opportunities to negotiate labor market pension schemes (Schmähl 2003). The reform was layered on the top of the old pension system, which will alter the public-private income mix of future generations of pensioners. The 2001 reform also paved the way for new actors, mainly private insurance companies, to enter the inner circle of German pension policy-making. Because of the far-reaching tax incentives it created, this reform also gave the Ministry of Finance important veto power over this policy area, something it did not have in the past (Rüb and Lamping 2005).

As mentioned above, in 2004, this 'direction setting law' (Rüb and Lamping 2005: 2) was complemented by two reforms that openly rejected the idea that pensions provided by the first pillar could maintain the pensioner's standard of living, which had been the norm since 1957. Under the heading of a 'sustainability factor', the replacement rate of the first pillar was further reduced. Taken together, the gross replacement rate of the first (public) pillar was reduced by the reforms in 2001 and 2004 from 48,7 per cent to 39,9 per cent (DIA 2007, OECD 2007). Its construction enables the government to adjust pension increases in an ad-hoc fashion if the combined contribution rate of employers and employees threatens to rise above the fixed limit of 20 per cent. Additionally, following a verdict of the German Constitutional Court, the second reform will make future pension benefits taxable, which implies a further reduction in the net replacement rate.

Undoubtedly, many elements of the old system remain and, for most retired Germans, the first pillar remains the main source of pension income. In fact, the reduction of benefit levels will only become noticeable to those who retire after 2010 at the earliest. 
Nevertheless, the logic and the public-private mix of the German pension system have fundamentally changed. The role of the first pillar has been reduced and will further decline in the future. Until today, the incentives of the 'Riester-Rente' have only been used sparingly, especially targeting lower income workers. However, in 2005, under the Grand Coalition, the government announced that mandatory private or occupational pension schemes were not necessary because coverage rates for both private and occupational voluntary schemes had significantly increased (Rentenbericht 2005). Hence, a reform of these schemes is currently not on the political agenda. To further dampen future expenditure growth for the first pillar, the Grand Coalition decided to increase the current retirement age from age 65 to 67 . This change will be gradually implemented between 2007 and 2029.

Incrementally, the public-private mix and the logic of the whole German pension system have significantly changed due to the above-mentioned reforms. The future replacement rate of the first pillar will be significantly lower than it is today, and the consensus among political leaders is that the growing importance of occupational and private supplementary pensions is unavoidable. The proto-typical Bismarckian German pension system has thus started to change its path largely through the institutional layering (Béland 2007) of supplementary and voluntary pension schemes on the top of decreasingly generous public pension schemes.

\section{CONCLUSION}

Since the 1980s, in the German welfare state, the public-private mix for health care and pension policies has changed significantly. For example, most post-1982 governments increased private co-payments in health care and, since 2001, the red-green governments 
have strengthened the market for private and occupational pensions. These market-building efforts involved the implementation of new state regulations aimed at regulating increasingly large social policy markets. As a consequence, the relationship between the state and the market has become even more complex than before, never approaching a clear-cut division between both sectors. The contours of the private and the public in German social policies are becoming increasingly blurred. The push towards 'risk shifting' (Hacker 2004, 2006) went hand in hand with a further increase in public market regulations. Hence, the state now faces the challenge of regulating dynamic markets in order to fulfill long-standing but less solidaristic social security goals under these new circumstances.

This greater policy complexity is most clearly observable in pension policies. On the one hand, the red-green governments build up the market for private and occupational pensions. On the other hand, intense regulations for these private pension products were introduced. For example, far-reaching tax subsidies that mainly targeted lower income employees were implemented. In light of these changes, the OECD rightly concludes that the 'recent pension reforms in Germany are among the most substantial and comprehensive among OECD countries' (OECD 2007). These changes do not imply a full retreat of the state. In contrast, recent pension reforms further blurred the boundaries between the public and the private sectors, and introduced tax policies into the pension policy framework.

Like in other countries, the political logic behind these developments is mediated through specific decision-making institutions and the policy legacies of existing social security schemes. Yet, even in the field of pension policy, the 'locus classicus' of path dependency arguments (Myles and Pierson 2001), the red-green governments favored an incremental shift towards a new institutional path that combines private markets and comprehensive public regulation (Jochem 2007). These remarks about pension reform in 
Germany suggest that institutional accounts focusing on path dependency often neglect the consequences of institutional layering (Béland 2007) as well as the fact that small policy changes may culminate over time to generate path departing dynamics (Thelen 2004).

As far as the German public-private mix is concerned, future developments are difficult to predict. Under the current Grand Coalition, further pension reforms have already been implemented (for example, the stepwise increase of retirement age). Today, most policy experts, even including the OECD (2007), argue that, in this policy area, structural reforms have been successfully accomplished. As for health care, the programmatic differences between the CDU/CSU and the SPD seem insurmountable. Considering this barrier, the outcome of the next national elections, which may take place in 2009, will probably shape the future of the public-private mix in health care. As mentioned above, while the CDU/CSU favors pro-market liberalizations, the SPD, in contrast, supports solutions that strengthen the existing public statutory health insurance. Because health care issues remain very high on the political agenda, the next electoral campaign probably will focus on these issues, which are at the heart of the changing relationship between public and private social policy in Germany. It seems, however, possible to predict that whatever reforms we will experience in the future, they will presumably further increase the complexity of the public-private mix in Germany, and they will presumably further blur the boundaries between 'public' and 'private' in the German welfare state.

\section{REFERENCES}

Béland, Daniel. 2007. 'Ideas and Institutional Change in Social Security: Conversion, Layering, and Policy Drift.' Social Science Quarterly 88: 20-38. 
Bleses, Peter and Martin Seeleib-Kaiser. 2004. The Dual Transformation of the German Welfare State. New York: Palgrave/Macmillan.

Busse, Reinhard and Annette Riesberg. 2004. Health Care Systems in Transitions: Germany. Copenhagen: WHO Regional Office for Europe on behalf of the European Observatory on Health Systems and Policies.

Castles, Francis G. 2004. The Future of the Welfare State: Crisis Myths and Crisis Realities. Oxford: Oxford University Press.

DIA (Deutsches Institut für Altervorsorge). 2007. Nachhaltigkeit verbessert - Gefahr der Altersarmut gestiegen: Das deutsche Rentensystem nach den Reformen. Pressemitteilung Retrieved from www. dia-vorsorge.de.

Frerich, Johannes and Martin Frey. 1993. Handbuch der Geschichte der Sozialpolitik in Deutschland: Von der vorindustriellen Zeit bis zum Ende des Dritten Reiches. München: Oldenbourg.

Greß, Stefan. 2006. 'Regulated Competition in Social Health Insurance: A Three-Country Comparison.' International Social Security Review 59: 27-47.

Greß, Stefan, Anke Walendzik and Jürgen Wasem. 2005. Nichtversicherte Personen im Krankenversicherungssystem der Bundesrepublik Deutschland-Bestandaufnahme und Lösungsmöglichkeiten. Expertise für die Hans-Böckler-Stiftung. Essen: Hans-Böckler- 
Stiftung.

Hacker, Jacob S.. 2004. 'Privatizing Risk without Privatizing the Welfare State: The Hidden Politics of Social Policy Retrenchment in the United States.' American Political Science Review 98: 243-60.

Hacker, Jacob S. 2006. The Great Risk Shift: The New Economic Insecurity - And What Can Be Done About It. New York: Oxford University Press.

Hall, Peter A.. 1993. 'Policy Paradigms, Social Learning, and the State: The Case of Economic Policymaking in Britain.' Comparative Politics 25: 275-296

Hering, Martin. 2002. 'The Politics of Privatizing Public Pensions: Lessons from a Frozen Welfare State.' Presentation prepared for American Political Science Association 98th Annual Meeting. Boston, 29 August - 1 September 2002.

Hinrichs, Karl. 1998. 'Reforming the Public Pension Scheme in Germany: The End of the Traditional Consensus?' ZeS-Arbeitspapier 11/98. Bremen: Centre for Social Policy Research.

Hinrichs, Karl. 2004. 'Alterssicherungspolitik in Deutschland: Zwischen Kontinuität und Paradigmenwechsel.' In Petra Stykow and Jürgen Beyer (eds.), Gesellschaft mit beschränkter Hoffnung: Reformfähigkeit und die Möglichkeit rationaler Politik: 266-86. Wiesbaden: VSVerlag. 
Immergut, Ellen M. 1992. Health Politics: Interests and Institutions in Western Europe. Cambridge: Cambridge University Press.

Immergut, Ellen M., Karen Anderson and Isabelle Schulze (eds.). 2007. The Handbook of West European Pension Politics: Political Institutions and Policy Outcomes in Comparative Perspective. Oxford: Oxford University Press.

Jochem, Sven. 2007. Reformpolitik im Wohlfahrtsstaat. Deutschland im internationalen Vergleich. Habilitationsschrift Humboldt-Universität zu Berlin.

Kohli, Martin, Martin Rein, Anne-Marie Guillemard and Hermann van Gunsteren (eds.). 1991. Time for retirement: Comparative studies of early exit from the labor force. New York: Cambridge University Press.

Lehmbruch, Gerhard. 1998. Parteienwettbewerb im Bundesstaat. Regelsysteme und Spannungslagen im Institutionengefüge der Bundesrepublik Deutschland. 2., erweiterte Auflage. Opladen: Leske+Budrich.

Myles, John and Paul Pierson. 2001. 'The Comparative Political Economy of Pension Reform.' In Paul Pierson (ed.), The New Politics of the Welfare State: 305-33. Oxford: Oxford University Press.

Nullmeier, Frank, and Friedbert W Rüb. 1993. Die Transformation der Sozialpolitik: Vom Sozialstaat zum Sicherungsstaat. Frankfurt am Main: Campus. 
OECD 2006: OECD in Figures 2006-2007. Paris: OECD.

OECD 2007: Pensions at a Glance. Paris: OECD.

Rein, Martin, and Lee Rainwater. 1986. 'Introduction.' In Martin Rein and Lee Rainwater (eds.),Public/Private Interplay in Social Protection: vii-vii. Armonk, NY: M.E. Sharpe, Inc.

Rentenbericht, 2005: Deutscher Bundestag. Drucksache 16/905.

Ritter, Gerhard A.. 2006. 'Der Preis der deutschen Einheit. Die Wiedervereinigung und die Krise des Sozialstaats'. München: Beck.

Rothgang, Heinz, Mirella Cacace, Simone Grimmeisen, Uwe Helmert and Claus Wendt. 2006. 'Wandel von Staatlichkeit in den Gesundheitssystemen von OECD Ländern.' In Leibfried and Zürn (eds.), Transformation des Staates: 309-54. Frankfurt am Main: Suhrkamp.

Rüb, Friedbert W., and Wolfram Lamping. 2005. 'The Politics of Reforming a ”Holy Grail”. Paradigm Shifts, Experimental Law-Making, and the Politics of German Pension Reform.' Paper presented at the ESPAnet Conference, 22-24 September 2005, Fribourg.

SBA (Statistisches Bundesamt). 2006. Gesundheit. Ausgaben, Krankheitskosten und Personal 2004. Wiesbaden: Statistisches Bundesamt 
Scharpf, Fritz W. 1998. 'The Joint Decision Trap. Lessons from German Federalism and European Integration.' Public Administration 66: 239-78.

Scharpf, Fritz W. 2006. 'The Joint-Decision Trap Revisited.' Journal of Common Market Studies 44: 845-64.

Schmähl, Winfried. 2003. 'Dismantling the Earnings-Related Social Pension Scheme: Germany Beyond a Crossroad.' ZeS-Arbeitspapier 9/03. Bremen: Zentrum für Sozialpolitik, Universität Bremen.

Schmähl, Winfried and Stefan Böhm. 1996. 'Supplementary Pensions in the Federal Republic of Germany,' In Emmanuel Reynaud, Lucy Aproberts, Bryn Davies (eds.), International Perspectives on Supplementary Pensions: Actors and Issues: 7-15. Westport: Quorum Books.

Schmidt, Manfred G. 2005. 'Sozialpolitik in Deutschland.' Historische Entwicklung und internationaler Vergleich. 3., völlständig überarbeitete und erweiterte Auflage. Wiesbaden: VS Verlag.

Schulze, Isabelle, and Sven Jochem. 2007. 'Germany: Beyond Policy Gridlock.' In Ellen M. Immergut, Karen Anderson and Isabelle Schulze (eds.), The Handbook of West European Pension Politics: Political Institutions and Policy Outcomes in Comparative Perspective: 660-710. Oxford: Oxford UP.

SVR (Sachverständigenrat zur Begutachtung der gesamtwirtschaftlichen Entwicklung). 
2006. Jahresgutachten 2006/2007. Wiesbaden: SVR.

Thelen, Kathleen. 2004. How Institutions Evolve: The Political Economy of Skills in Germany, Britain, the United States and Japan. New York: Cambridge University Press.

Trampusch, Christine. 2005. 'Sozialpolitik in Post-Hartz Germany.' WeltTrends 47: 77-90.

Wehler, Hans-Ulrich. 1995. Deutsche Gesellschaftsgeschichte, Dritter Band: Von der „Deutschen Doppelrevolution’ bis zum Beginn des Ersten Weltkrieges 1849-1914. München: Beck. 